v. 7, n.3

Vitória-ES, sept. - dec. 2010.

p. 23 - 44 ISSN 1808-2386 DOI: http://dx.doi.org/10.15728/bbr.2010.7.3.2

\title{
Cultural management in family business
}

\author{
Patricia Amelia Tomei ${ }^{\dagger}$ \\ PUC-Rio \\ Patrícia Jaguaribe Ferrari $^{\Omega}$ \\ PUC-Rio
}

\begin{abstract}
This article's main goal is to analyze how the evolution of organizational culture can impact business performance. A theoretical framework was developed based on a review of the literature relating to organizational culture and family business succession management models. A single case study methodology was adopted based on primary and secondary data obtained through documentary research, participant observation and interviews at Guapo Loco, a Brazilian chain of Mexican restaurants / fun bars, which is a family company and was founded in Rio de Janeiro in 1996. We focused on its leader's trajectory and its implications for the life cycle of the family business, the founder's dream and vision, succession and cultural management difficulties. We conclude that it is possible for an organization to become trapped by its cultural formation. We will see that as it reaches maturity, the organizational, family and shareholder dimensions need to adapt in a similar fashion. At this stage, the organizational culture may become dysfunctional, jeopardizing the organization's survival.
\end{abstract}

Key words: Organizational culture, family business, cultural management.

Received in 08/22/2008; revised in 07/13/2010; accept in 07/20/2010.

Corresponding authors*:

${ }^{\dagger} \mathrm{Ph}, \mathrm{D}$. in Administration by the University of São PauloUSP.

Affiliation: Associate Professor of the PUC-Rio

Address: Rua Professor Mikan, 80, São Conrado 22610-250

Rio de Janeiro.

E-mail: patomei@iag.puc-rio.br

Telephone: (21)21389200/021 97673048
$\boldsymbol{\Omega}$ Master in Administration by the PUC-Rio.

Affiliation: Professor lecturer of the PUC-Rio

Address: Rua Xavier da Silveira, N. 92 ap. 801, Copacabana,

Rio de Janeiro, R.J., CEP 22061-010

E-mail: Pferrari@uninet.com.br

Telephone: ( 21 ) 99148037

Editor's note: This paper was accepted by Antonio Lopo Martinez. 


\section{INTRODUCTION}

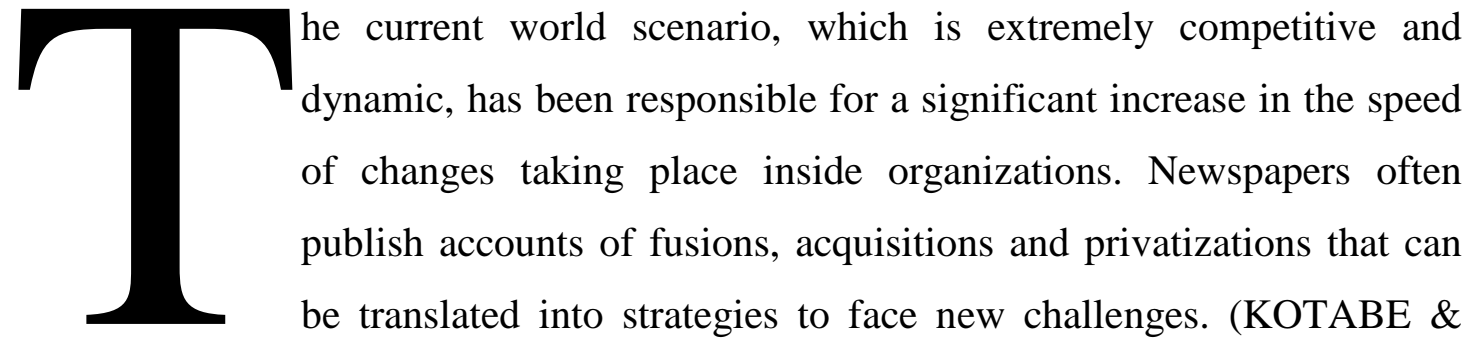
HELSEN, 2000; HAMEL \& PRAHALAD, 1985).

According to Zago (2000), the variability of the environment and economic uncertainty promote a constant flow of product innovation, flexibility and development, and organizations are embracing these challenges. Recent research has confirmed these actions and they has shown that innovative firms tend to have a higher market share, growth and earnings.( KOTLER,1999; QUINN,1998; ARRIGHI,1996; CANCLINI,2003; HARVEY,1992; VAKALOUIS,2001).

The organizations that have acquired this vision are rethinking their attitude, and attaching more importance to knowledge and structural reconfigurations that enhance flexibility and dynamism, qualities that both require constant changes and innovation and are crucial for company performance. (ANDREWS \& DOWLING, 1998; SAFFOLD, 1988; DENISON \& MISHRA, 1995, MARCOULIDES \& HECK, 1993).

For many years the organizational literature focused on mature organizations instead of analyzing their birth stage.

As a result, it was only in the 1980's that studies of the development of new organizations from a longitudinal perspective began to appear, when various authors suggested that organizational design, change, development and behavior could be forecast by using life cycle models (ADIZES, 1979).

This analytical perspective affirms that a firm's evolutionary process is composed of various stages, each with its particular characteristics, organizational behaviors and managerial practices that are associated with shared values.

It is necessary to know these stages with their challenges, practices, values and dominant profiles in order to undertake cultural management and develop strategies and action plans that aim at improving organizational performance.

Although there are countess organizational life cycle models \{(Quinn and Cameron (2006), Greiner (1972) and Adizes (1979)\}, the author that is most prominent in the literature 
regarding the relation between life cycles and organizational culture model is Schein (1985), who states formally that organizations possess growth stages, in which the function of culture changes according to the specific phase they are in.

In this study we will associate the analysis of cultural typologies, designed to identify the predominant type of culture, with Schein's (1985) model in order to understand the impact of this culture on the different phases of a family organization's life cycle and performance.

In order to achieve this objective, we will describe our methodology in the next stage (item 2) and in item 3, the theoretical references, we will present concepts related to organizational culture (formation, role of founders and typologies) and family business. Finally, in item 4, we will present our results, that will be analyzed in item 5.

\section{METHODOLOGY}

The research began with a literature review, and a study of the main concepts relating to organizational culture, family business and cultural management and used methodologies and cultural typologies.

The next step was to perform a case study of the company called Guapo Loco Mexican Food, a Brazilian chain of Mexican restaurants / fun bars, which is a family company founded in Rio de Janeiro in 1996.

This research collected data through a multi-method study that included documental analysis, workshops, observations and 23 individual interviews using open-ended questions with founders, leadership and middle management.

The following documents were analyzed during the documental research phase: company history, philosophy, organizational structure, human resources practices, strategic plan, vision and mission, social responsibility actions, employee manual, socialization process, communication process, organizational structure, reward system, level of formality, leadership and written values.

Interviews were conducted in person and ranged in length from 60 minutes to two hours. The primary purpose of the interviews was to identify the following organizational and attitudinal variables: the main challenges, difficulties and opportunities encountered during the organizational life cycle; shared meaning of existence in the organization; communication process; decision making process; and the role of leadership in the organizational change process. 
The study's reliability was improved by emphasizing the confidentiality of the discussions and respondent anonymity. In addition, due to the non-probabilistic nature of the convenience sample, the study's results cannot be generalized.

The information obtained through interviews included opinions, thoughts, interpretations and perceptions that were analyzed using a qualitative approach.

This analysis of the interviews' content was complemented by information derived from participant observation, given that one of the researchers was a member of the organization's formal structure, and thus, in the words of Cruz Neto (1994, p. 21) there was a "direct contact between the researcher and the observed phenomenon, in a quest for information regarding the social reality of social actors in their own contexts".

However, identifying an organizational culture and gaining an understanding of its contents a complex matter. Typology construction is an appropriate scientific tool that is quite often used to analyze and identify complex contents of social reality such as organizational culture. (FREITAS, 1991)

The aim of typology construction (both theoretical and empirical) is to classify and clarify the complex content of social reality and to find a group of selected values that govern the company. Typologies have a highly practical importance because they enable researchers to compare the contents of different organizational cultures. A number of organizational culture typologies have been published. (DAFT, 2008; SCHWARTZ, 1999; QUINN. \& ROHRBAUGH,1983; GOFFEE \& JONES ,1996; SETHIA \& VON GLINOW ,1985; HANDY,1979; DEAL \& KENNEDY ,1982; DONNELY ,1984; TROMPENAARS,1994; BARROS \& PRATES, 1996 ;HOFSTEDE, 1991.)

In this study we selected the following typologies on which to base the analyses: Sethia \& Von Glinow (1985), Handy (1979), Deal \& Kennedy (1982), and Donnely (1984).

\section{THEORETICAL REFERENCE POINTS}

\subsection{Organizational Culture}

\subsubsection{Definitions}

The analysis of organizations from a cultural perspective has been a constant theme of study in recent years. As we have become increasingly aware of the symbolic aspects of organizations, we have gained a new perspective from which to understand them, and it is this understanding that can explain their origin and development. The concept of culture and organizational culture in particular, has already been defined in the most diverse ways . Some 
definitions emphasize the strategic side, and others the operational and sociological sides. (TOMEI et. al., 2008)

Schein $(1984,1986)$ defines organizational culture as a series of assumptions invented and developed by a group of persons, in the course of learning how to adapt to the business environment, as well as dealing with internal integration challenges. If the group accepts the fact that these "solutions" work (and while they do) they will be internalized, and the assumptions will henceforth be unconsciously assimilated and passed on to new members of the organization. This, according to Schein (1983) is how an organizational culture is created.

According to Schein $(1990,1993)$, organizational culture can be analyzed at different levels constituted by visible artifacts, values that govern the behavior of people and basic unconscious, invisible presuppositions that are taken for granted. These three levels represent an increasing degree of difficulty in the analysis. According to Schein's methodology for deciphering an organization's culture, it is necessary to expand on its basic presuppositions, or in other words, its cultural paradigm.

Leadership is the original source of the beliefs and values that enable a group to start dealing with its internal and external problems. If a leader's proposals work and continue to work, what began as solely the leader's assumption gradually becomes a shared assumption. Once a set of shared basic assumptions is formed by this process, it can function as a cognitive defense mechanism both for the individual members and for the group as a whole. In other words, individuals and groups seek stability and meaning. Once these are achieved, it is easier to distort new data by denial, projection, rationalization, or various defense mechanisms than to change the basic assumption.

The controversial matter of culture management has been the subject of a great number of studies, especially those relating to cultural transformation. However, Schein (1985b) states that changing an organization's culture, in the sense of changing basic assumptions is very difficult, time consuming, and causes a high level of anxiety.

\subsubsection{The founder's vision / dream}

Companies are usually created by founders who have a vision of the business and service or product which they will create and produce. According to Schein (1983), entrepreneurs have strong views regarding the nature of the business world, which they derive from their own experience, personality and the culture in which they were brought up. Founders internalize these cultural traits in the new organization by means of a set of 
mechanisms, which range from informal teaching, accounts of past experiences and even those related to rewards and status.

Lipton (2003) suggests that the culture created based on the founder's vision or dream, generates more control than norms or formal procedures. Sometimes an extreme devotion to the founder's culture takes on an almost religious form, with members becoming totally identified with it, and accepting and assuming its values, beliefs and behavior.

\subsubsection{Shaping of organizational culture}

The founders play a major role in initiating the development of an organization's culture (Figure 1). They transmit their experiences based on the culture in which they grew up through mechanisms described by Schein (1983) to the group they lead, and these experiences are internalized as solutions to the problems of internal integration as well as external adaptation. The resulting organizational culture is a mix of values, beliefs and principles shared by the organization. These cultural elements are frequently learned in a non-explicit way, but are only accepted when the group perceives that the solutions are working.

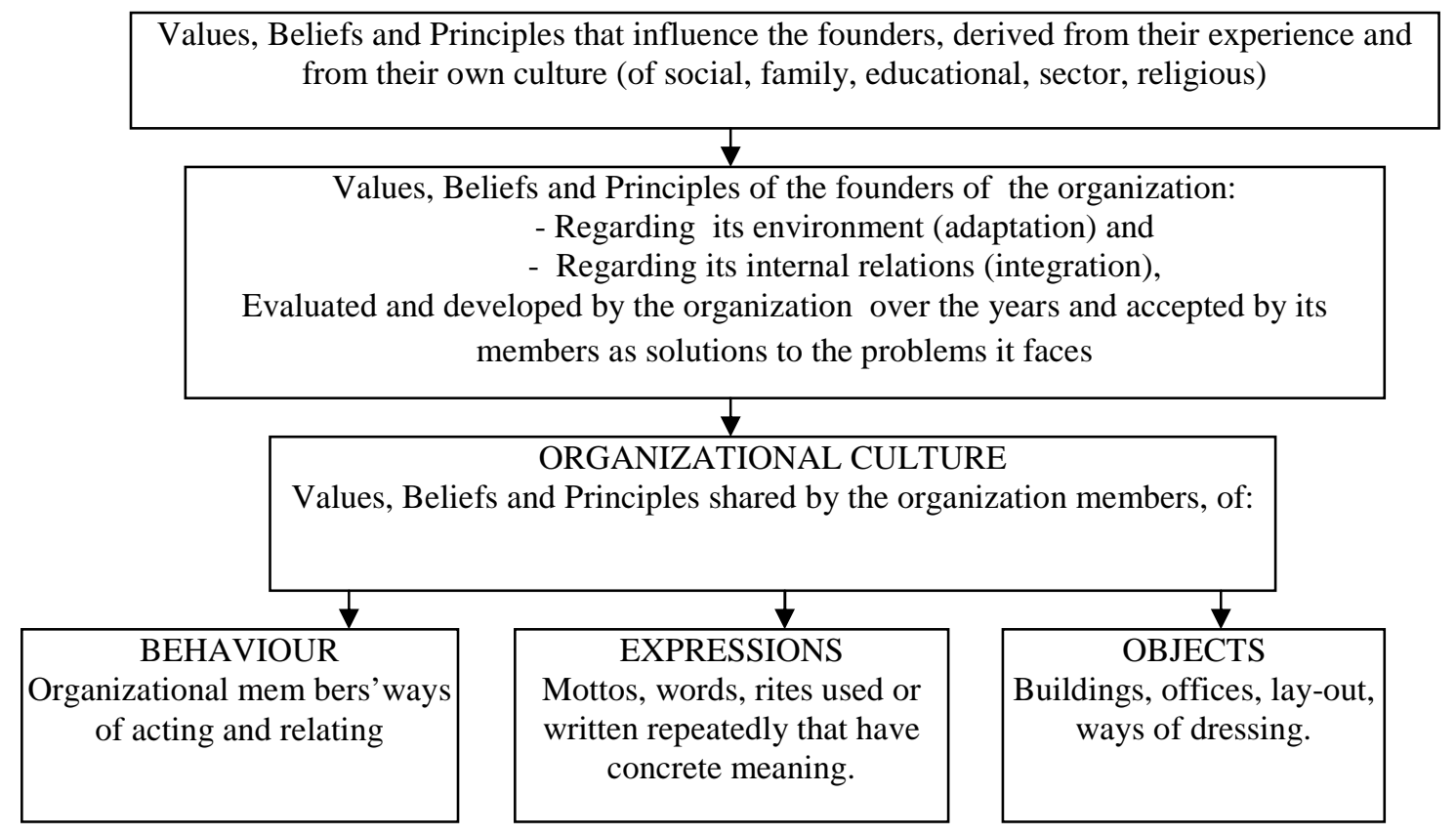

Figure 1: Role of the founders in building organizational culture Source: Freitas, M. E. (1991)

According to Schein (1985a), organizations possess a multi-stage life cycle and the organizational culture assumes different functions during each of these stages. By analyzing an organization's specific stage, it is possible to identify the most appropriate moments and 
most efficient mechanisms for managing organizational culture, as shown below in summarized form in Table 1:

Table 1: Growth stages, function of culture and change mechanisms

\begin{tabular}{|c|c|c|}
\hline Growth stages & Function of Culture & Change Mechanisms \\
\hline \multicolumn{3}{|c|}{ I - Birth and first stages of growth } \\
\hline Family domination & $\begin{array}{l}\text { Competence demarcation and source of identity. } \\
\text { "Glue" that binds the company together. } \\
\text { The organization seeks integration. } \\
\text { Strong emphasis on socialization. }\end{array}$ & \multirow{2}{*}{$\begin{array}{l}\text { 1.Natural evolution } \\
\text { 2.Self-guided evolution } \\
\text { 3.Management evolution through } \\
\text { personalities } \\
\text { 4.Management revolution } \\
\text { undertaken by outsiders }\end{array}$} \\
\hline Succession phase & $\begin{array}{l}\text { Culture becomes a battlefield for liberals and } \\
\text { traditionalists. } \\
\text { Successors are judged to see whether they will } \\
\text { preserve cultural values. }\end{array}$ & \\
\hline \multicolumn{3}{|c|}{ II - Organizational Mid-Life } \\
\hline $\begin{array}{l}\text { New products } \\
\text { Vertical integration } \\
\text { Geographical expansion } \\
\text { Mergers and acquisitions }\end{array}$ & $\begin{array}{l}\text { Cultural integration declines as new sub-cultures are } \\
\text { developed. } \\
\text { Opportunity for guiding the direction of cultural } \\
\text { change. }\end{array}$ & $\begin{array}{l}\text { 5. Planned change } \\
\text { 6. Technology seduction. } \\
\text { 7.Through scandals, } \\
\text { explosion } \\
\text { 8. Instrumentality } \\
\end{array}$ \\
\hline
\end{tabular}

\section{III - Organizational Maturity}

\begin{tabular}{|c|c|c|}
\hline $\begin{array}{l}\text { Markets maturity } \\
\text { Stagnation/internal stability } \\
\text { Lack of motivation for } \\
\text { change }\end{array}$ & $\begin{array}{l}\text { Culture becomes resistant to innovation. } \\
\text { Preserves glories from the past, is valued as a source } \\
\text { of self-esteem. }\end{array}$ & \\
\hline Transformation options: & $\begin{array}{l}\text { Cultural change is necessary. } \\
\text { Essential elements of the culture should by identified } \\
\text { and preserved. } \\
\text { Cultural change is possible or it can be allowed to } \\
\text { develop. }\end{array}$ & 9.Coercive persuasion \\
\hline $\begin{array}{l}\text { Struction options: } \\
\text { Bankruptcy and } \\
\text { reorganization. } \\
\text { Takeover and } \\
\text { reorganization. } \\
\text { Merger and assimilation. }\end{array}$ & $\begin{array}{l}\text { Culture changes at basic levels. } \\
\text { Culture changes through a massive turnaround of key } \\
\text { persons. }\end{array}$ & $\begin{array}{l}11 \text { Reorganization, destruction and } \\
\text { rebirth }\end{array}$ \\
\hline
\end{tabular}

Source: Schein, Edgar H. "How Culture Forms, Develops, and Changes", in: Kilmann et al. Gaining Control of the Corporate Culture. São Francisco: Jossey-Bass, 1985.

\subsubsection{Cultural typologies}

The study of cultural typologies is a useful tool to achieve an understanding of different cultures and can be very helpful in identifying a company's culture's stage of evolution. In our work we used four cultural typologies described below:

\subsubsection{1 .Sethia\& Von Glinow (1985)}

This classification is based on the importance of the reward system as a way of managing an organization's culture, because of the strong interdependence between reward and culture. Based on the behavior of this interdependence and the orientation of the organization in terms of human resources and performance, the authors develop a model in which they define four basic forms of organizational culture: Caring, Integrative, Apathetic or Exacting. These 
typologies reflect an organization's degree of concern regarding people and performance and the cultures so defined can be organized into four quadrants. (Table 2).

Table 2: Sethia \& Von Glinow organizational culture typology

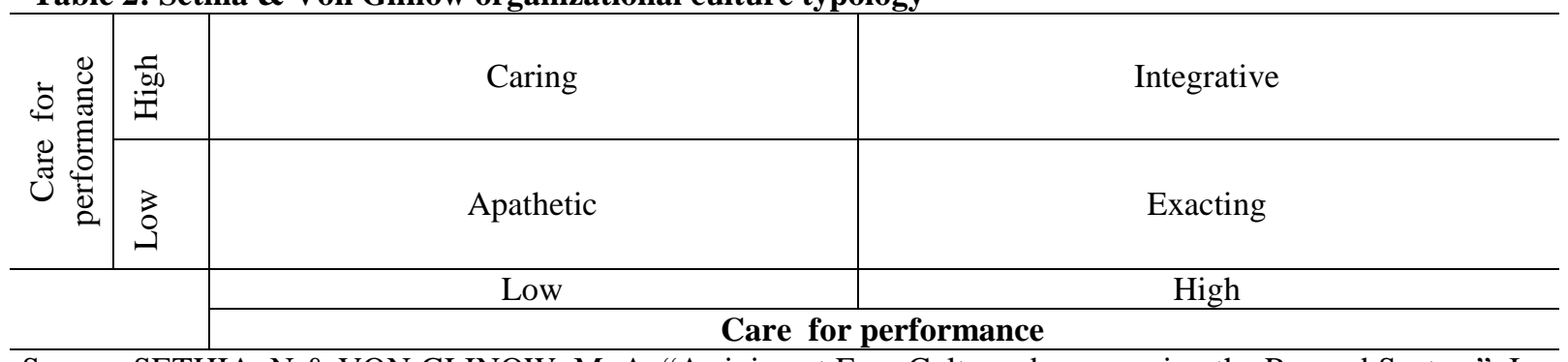

Source: SETHIA, N \& VON GLINOW, M. A. "Arriving at Four Cultures by managing the Reward System", In: Kilmann et al. Gaining Control of the Corporate Culture, San Francisco: Jossey Bass, 1985.

Apathetic culture: indifference regarding people or performance. State of low morale and cynicism permeates the organization and its leaders show incompetence in this situation. Its survival is complicated, but it can persist by virtue of its strong market positioning or sheer size. Reward system is not transparent and fails to recognize both good performance and failure.

Caring culture: highly caring towards people and does not demand high levels of performance. Its paternalistic character may be present in the founders' or leaders' philosophy. Reward system related to job security, teams, cooperation and conformity.

Exacting culture: little concert with people and is performance oriented. Huge rewards, but highly variable: "survival of the fittest".

Integrative culture: both aspects (people and performance) are mutually reinforcing Its concern with people is not paternalistic but, differently from an exacting culture, people are respected and the aim is to attract and retain talents.

\subsubsection{Charles Handy (1979)}

Based on Roger Harrison's studies of organizations' nature and ideology, the author develops another classification of an organization's culture by analyzing how its power channels are reflected in its systems and structures. His model analyses questions involving power and its consequences for the organization's structure and systems, classifying organizational culture into four basic forms: Power, Role, Task and Person cultures.

Power culture: its structure resembles a web with power located at the center. Characterized by a small number rules or proceedings, judgment by results, a focus on the individual and control exercised by the center. Leaders with a power-oriented and political mentality profile are the ones that would fit better into this culture. 
Role culture: the perfect example would be a bureaucratic system, with a logical and rational orientation. Characterized by safety and predictability, may be found in industries where economies of scale are more important than flexibility or when technical features and specialization are more critical than innovation.

Task culture: oriented towards a specific job or project. Team work is highly stimulated and it fits markets where flexibility, speed, creativity and sensitivity regarding market changes are fundamental.

Person culture: seldom found, this type of culture's main focus is the individual. No objective takes precedence over persons, who join together in order to support each other to achieve individual goals.

\subsubsection{Deal \& Kennedy (1982)}

According to these authors, organizational culture, as in Sethia \& Von Glinow's typology, is based on two factors: the risk level associated with the company's activities and the speed with which the company and its employees receive feedback on its strategic decisions and whether these strategies have been successful. Based on these premises, the authors classify organizational culture as: Tough Guy/Macho culture, Work Hard/Play Hard, Bet your Company and Process culture.

Table 3: Deal \& Kennedy organizational culture typology

\begin{tabular}{|c|c|c|c|}
\hline \multirow{2}{*}{ 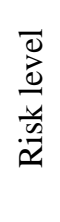 } & 臬 & Tough Guy/Macho & Bet your company \\
\hline & ב) & Work hard / play hard & Process \\
\hline & & Fast & Slow \\
\hline & & \multicolumn{2}{|c|}{ Feedback speed } \\
\hline
\end{tabular}

Source: HANDY, C. Deuses da Administração: Como enfrentar as constantes mudanças da cultura empresarial. São Paulo: Saraiva, 1979.

Tough Guy/Macho culture: highly individualistic environment with high level of risk tacking and rapid feedback. Speed oriented culture, where decisions are taken fast and are competitive and very short-term oriented: surgeons, consulters, sports and financial markets.

Work hard / play hard culture: companies with a high volume of work, but which is not vital. Fast feedback but low risk level: Avon, Mc Donald's, Sears and other.

Bet your company culture: slow feedback and high level of risk, typically in companies with huge investments and slow returns as in the pharmaceutical industries, oil and 
mining companies, as well as research centers. People are self-guided, respect technical competence and share knowledge.

Process culture: low risk and slow feedback: banks, government agencies and industries with a high level of regulation. People are more concerned with "how" than with "what", with a focus on technical perfection.

\subsubsection{Donnelly (1984)}

This author identifies three cultural forms, which are related to planning and highly influenced by the leader's personality. These are: Excellent, Fuzzy and Awful.

Excellent culture: highly planed, the organization as well as its people has a clear notion of the company's mission. Communication flows perfectly, everyone exactly where they're headed, and what is expected of them.

Fuzzy culture: there is no clear course and is frequently found in organizations with a high leadership turnover. Does not innovate.

Awful culture: constantly in a state of crisis. People are always putting out fires. Unpleasant atmosphere, usually run by owners or families who think they know what's best for everyone, always. .

\subsection{Family business}

Although family businesses are the world's largest employers and account for almost half of the world's GDP, they seem to contain the seeds of their own destruction as few of them survive until their first generational change (DAVIS, Jet al., 1997). Nonetheless it would be wrong to assume that these constraints prevent them from becoming more than just small or medium sized companies. Some of the world's largest companies such as Wal Mart Stores, Ford Motors, Samsung and LG groups, Fiat, PSA Peugeot Citroën, BMW, Motorola Inc. are controlled by families.

Therefore there are processes that enable organizations that are born out of an entrepreneur's dream or vision, to transform themselves into mature companies, with the ability to perpetuate their business life through the cycles and phases that they will necessarily have to go through. According to Vidigal (1996) management studies usually focus on diversified capital companies or on those where control is concentrated in the hands of a few shareholders. In these organizations only two dimensions can be characterized: property and management. Family owned businesses add a new dimension to the two above: that of the family. After usually starting life as the result of their founders' intentions and work, these 
organizations become more and more complex as new family members enter them. Based on the study of family organizations and companies as systems,

Davis et al. (1997) developed the "Model of the three circles" (figure 2) which consists of the visualization of the three independent subsystems that are closely related in family business: business, family and ownership structure. This model enables the sources of the conflict and the desires of each member of the subsystems to be identified, thus helping to illustrate the nature of family business.

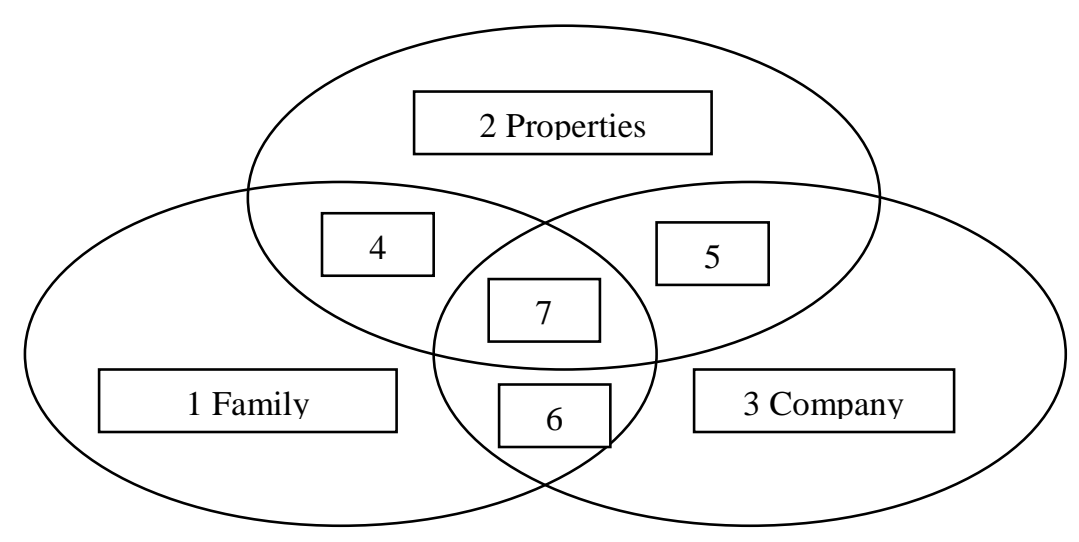

Figure 2: Model of the three circles.

Source: DAVIS, J., GERSICK, K., HAMPTON, M., LANSBERG, I. Generation to Generation: Life Cycle of Family Business. HBS Press Book, 1997.

This model shows several new areas of intersection, which increase the sources of possible conflict and the needs and wishes of every member of these subsystems. The understanding of the complex interactions (which correspond to areas 4 to 7 , in figure 2) between theses three subsystems will allow us to better analyze the problems affecting family organizations and their causes. For example a shareholder who is neither a member of the controlling family nor an employee will be in area 2.

A member of the family with stocks and a management position will be found in area 7. Each of these subsystems' specific interests can easily be perceived and this is what makes the "three circle model" widely accepted for its elegance and insight. For example, members of subsystem 4, meaning family members who hold stocks but do not have any management function, will be naturally inclined to demand larger dividend payments, unlike the members of area 6 (family, non stockholders but with management functions), and even those of area 7 , who usually have a more long- term view of the business. Understanding the complex interactions (areas 4, 5, 6 and 7 of the model) between these three subsystems make it easier 
to analyze the problems of a family company and its causes. This model was later extended to include the time variable, mainly due to the relative problematic to the above-mentioned problem of the succession plan's development. The new model, entitled "Development Model", projects the development of the three factors (business, ownership structure and family) over time, as shown below: (Figure 3).

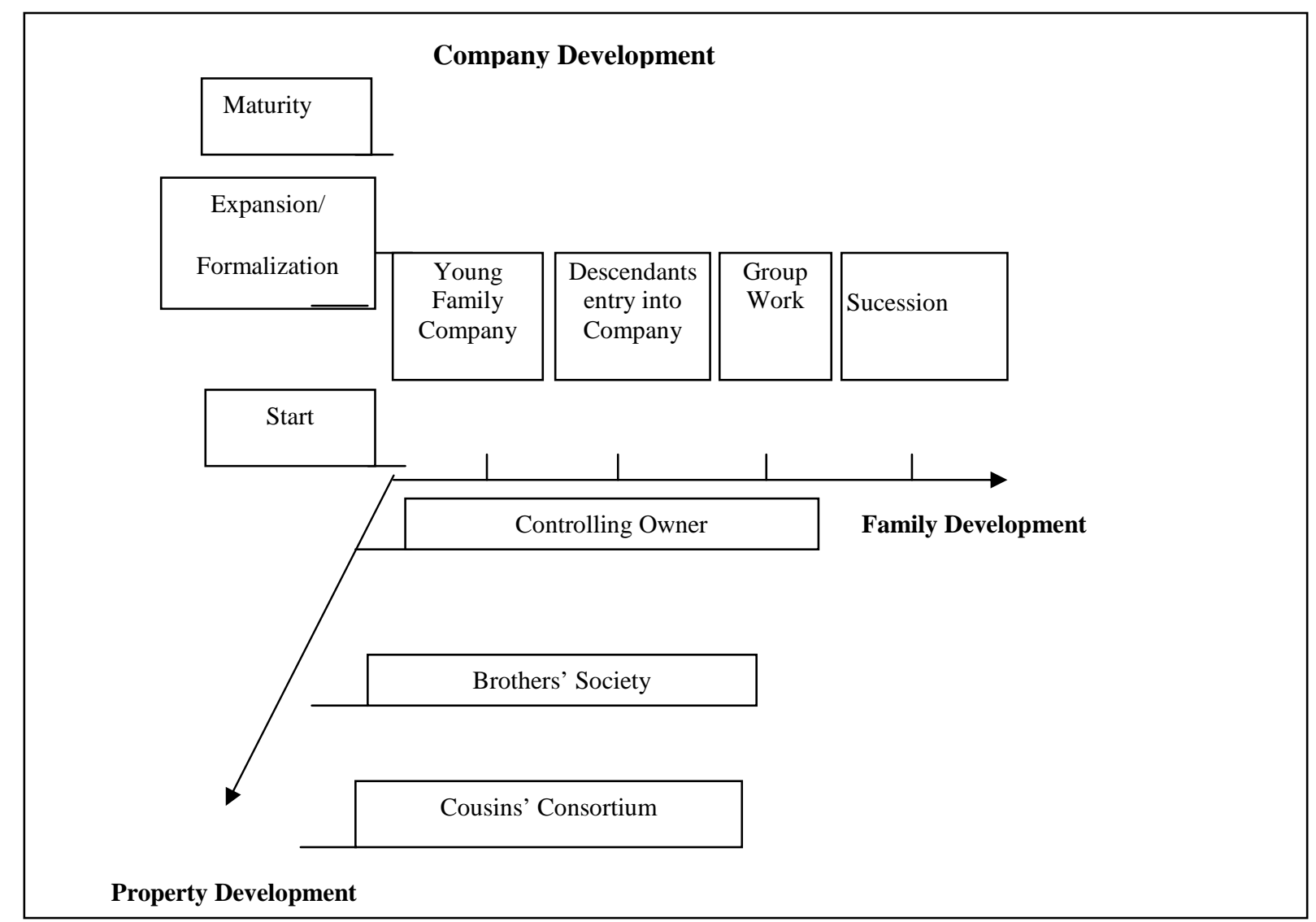

Figure 3: Three dimensional Development Model

Source: HSM Management - Empresas Familiares - O Desafio da Continuidade (2003).

The moments of transition between stages, along each of the three axes, are the most delicate and challenging and that require a greater attention from managers. A high level of $t$ worrisome uncertainty occurs during these moments, creating insecurity and anxiety in the organization. The way these transition periods are managed by the organization is crucial to the company's long-term success.

These changes require different efforts from those developed during periods of stability and growth, given that they are strategic activities and not tactical-operational ones. The first dimension, that of ownership, which is divided into three stages in the model can in fact be a combination of several others, instead of being limited to three categories. But there is a development direction underneath it, shown by this axis, which is the direction of 
ownership fragmentation. These three stages explain most of the changes that occur during the life of family owned businesses. The family dimension follows the development cycle of a family nucleus, and usually these stages occur inevitably. When control of the business becomes concentrated again, in the axis shown above (ownership dimension) the family cycle starts all over again.

In the company development dimension the three stages shown capture the main differences: there always is a starting point with its own characteristics, linked to the founder. Afterwards companies establish themselves in the market, with their operations reaching a stable level as they try to fit their growth curve and internal structures to the needs of the ownership group's evolution and the development of the family.

The final stage of business maturity has its root in market valuation, when its products begin to obtain lower margins and are no longer easily distinguishable from those of the competition. But maturity should not be seen as the final stage of the company's sustainable evolution. There are two possible exits from this stage for a family business: renewal and recycling or the death of the company.

Clearly the three dimensions do not have entirely independent dynamics, especially during their early stages. If a company is to develop in a healthy manner, on a course towards maturity and renewal, it must pass through a stage of openness and flexibility in both the ownership and family cycle dimensions. Lansberg (1988) reminds us that $70 \%$ of family companies are either sold or closed after the death or removal of its founder. This is mostly due to the fact that many positive characteristics associated with ownership and families are easily lost at this stage.

According to Vidigal (1996), succession constitutes the greatest moment of crisis for a family business and thus requires careful preparation and planning on the founder's part. $\mathrm{t}$ However, even planning of the succession by the owner and its acceptance by the rest of the family do not guarantee that the vision that gave birth to the organization's culture will be perpetuated.

The dimensions of the development model presented have to evolve in harmony, through the different stages with the appropriate change mechanisms, in which the organization's culture has a fundamental role. Once the succession has been concluded its vision of the future must be compatible with the organization's culture, and the latter with the organization's situation in each of the three dimensions. 
But one of the main questions that need to be answered, during the succession planning phase, depends on $t$ understanding the vision of the generation that is relinquishing control and of the one that is going to receive it. These perceptions, which may differ, form the organizational context in which succession occurs and determine whether the sons will be encouraged to enter the business, as well as how the organizational culture is perceived and whether it is accepted by the successors

\section{RESULTS: MANAGEMENT MODELS AND CULTURAL TYPOLOGIES}

\subsection{Guapo Loco history: the role of the family and leadership}

Our case study begins with the personal story of the organization's founder Carlos Davies, an entrepreneuring young Brazilian. He is the president and founder of Guapo Loco and has done a little of everything in his life: since his youth he showed his entrepreneurial talents fixing up surfboards or acting as D.J. at friend's parties.

He moved with his family to the U.S. at the age of 22 and began in the Food \& Restaurant business, first as a dishwasher, then assistant cook, working his way up to cumin, waiter, bartender and assistant manager. In San Diego, California, seeking a typical Brazilian's dream of following the surf waves, he started working at hotels as a banquet houseman, attaining positions such as: banquet manager assistant, banquet manager, Food \& Beverage Director's Assistant, until becoming the Food \& Beverage Director of three of the city's most prestigious hotels. He always was extremely hard working and showed dedication and loyalty to the firm. Some of his accomplishments were recognized and he won some international prizes and awards in the U.S.A.

In 1992, Carlos Davies had a good opportunity to come back to Brazil, as a partner in a firm.. But, due to a lack of experience and adaptation to cultural and professional practices in Brazil, the business failed Dreaming of having his own business, and in tune with the growing Mexican niche in Brazil, he decided to take a risky solo flight and open his own Mexican food restaurant. He founded the Guapo Loco. Over the space of ten years he expanded this first restaurant into a chain of five owned stores, Tex Mex Restaurants and two franchises, both using the Fun Bar model. The company is a family business, where three of the four Davies family brothers are owners. Their mother and two of their wives also work in the business.

\subsection{Guapo Loco: cultural diagnosis}

Despite the fact that the company has a stated mission, which is "High standard of quality food, with a commitment to Mexican authenticity, a fun place to be at, at a fair price" 
and values (hard work, loyalty, dedication, and commitment), the strategic purposes and the vision of the company have not yet been defined. A distinctive fact in the company's management is that professionalization is not a priority. There are no clear job roles, maybe due to the partnership characteristic of the business, run by a family. According to the Davies brothers Guapo Loco's management is based on "feeling". An academic of training and best practices are not valued. The company is administered as a continuation of the Davies' house.

Based on interviews and participant observation, we prepared Table 4 which sums up Guapo Loco's organizational diagnosis, in terms of its Communication System, Employee Relations, Organizational Structure, Level of Formality, Leadership, Reward System, Decision-Making Process, Values and Socialization Process.

Table 4- Guapo Loco organizational diagnosis

\begin{tabular}{l|l}
\hline \multicolumn{1}{c|}{ Item } & \multicolumn{1}{c}{ Description } \\
\hline Communication System & $\begin{array}{l}\text { The informal channels of communication are the most efficient way to } \\
\text { access the information system. }\end{array}$ \\
\hline Employees' Relations & Strong paternalism \\
\hline Organizational Structure & $\begin{array}{l}\text { Not well defined. Job positions, roles and accountabilities are also } \\
\text { undefined. }\end{array}$ \\
\hline Level of Formality & $\begin{array}{l}\text { Because leaders are brothers or members of the same family, inter personal } \\
\text { relations are absolutely informal }\end{array}$ \\
\hline Leadership & $\begin{array}{l}\text { Seen by the employees as the core business. Leaders count on a lot of } \\
\text { enthusiasm, dynamism and improvise. }\end{array}$ \\
\hline Reward System & $\begin{array}{l}\text { Informal system, without technical criteria to define promotions, benefits } \\
\text { and wages. }\end{array}$ \\
\hline Decision-making Process & $\begin{array}{l}\text { Totally centralized at the top. The employees have no delegation of } \\
\text { authority, or autonomy to make strategic decisions. }\end{array}$ \\
\hline Values & $\begin{array}{l}\text { Loyalty and affective commitment with the company, among employers } \\
\text { and employees, in a good and satisfactory climate. }\end{array}$ \\
\hline Socialization process & $\begin{array}{l}\text { Reinforced with informal meetings and rites as football game, barbecues, } \\
\text { birthdays or Christmas Party. Employees feel proud of belonging the } \\
\text { Guapo family. }\end{array}$ \\
\hline
\end{tabular}

Source: Primary data.

\subsection{Guapo Loco cultural diagnosis}

As presented in the theoretical references, according to Schein's (1993, 1990) methodology for deciphering the culture of an organization, it is necessary to expand on its basic presuppositions, or in other words, its cultural paradigm. In the Guapo Loco case, we can characterize this cultural paradigm through:

a) The physical working environment, which promotes informality, with the colorful restaurants, all decorated with Mexican features and the dress code is very casual, as this the idea the restaurant wants their customers to have.

b) Rites and ceremonies are the elaborate, planned activities that make up a special event and are often conducted for the benefit of an audience. At Guapo Loco we can perceive 
few or no demotion actions. Everything is done to avoid dismissals and to make these processes the most respectful and least traumatic possible. Actions of confirmation (or reinforcement) are the most practiced, mainly by promoting employees that are considered to be loyal and committed to the business. There are frequent transition and renewal actions. They are usually performed during training programs. They are always used in admissions, management changes and/or renewal of teams (team buildings, outside of the work environment). Other important socialization programs are conducted by the head office to promote integration among all branches, such as: Children's Day, soccer championships, ending with a huge event organized by the Human Resources Department, as well as Christmas Party.

c) Heroes of stories serve as role models. The tale about the saga of the company's president, who started his working life performing jobs like his employees, is a good example of a hero. The story emphasizes the president's values of the adventurous, hard working, innovating, fearless, enterprising spirit considered to be fundamental for the business.

d) Analyzing the four cultural typologies presented, and based on secondary and primary sources, it is possible to classify Guapo Loco's culture as in Table 5.

Table 5- Guapo Loco Cultural Typologies

\begin{tabular}{|c|c|}
\hline Model & Description \\
\hline Sethia \& Von Glinow (1985) & $\begin{array}{l}\text { Caring } \\
\text { Takes care of its members' welfare without imposing a high standard of } \\
\text { performance. } \\
\text { The company is concerned about the organizational environment and adopts } \\
\text { a paternalist position. }\end{array}$ \\
\hline Handy (1979) & $\begin{array}{l}\text { Person/power culture } \\
\text { The decision process is centralized, the central power exerts great influence } \\
\text { and the presence of the leader is very important. The company values } \\
\text { technical knowledge and team work influence in day to day activities. }\end{array}$ \\
\hline Deal \& Kennedy (1982) & $\begin{array}{l}\text { The tough-guy/Macho } \\
\text { The culture tends to be young, individualist. Speed -oriented culture, where } \\
\text { decisions are taken fast and are competitive, and very much short-term } \\
\text { oriented }\end{array}$ \\
\hline Donnelly (1984) & $\begin{array}{l}\text { The organization can be characterized as a Fuzzy culture, where everything } \\
\text { is uncertain and there is a high resistance to innovation. }\end{array}$ \\
\hline
\end{tabular}

Source: Primary data.

e) In relation to the organizational life cycle, based on Schein's (1985a) model, we can say that Guapo Loco is between the phase of Familiar Domination and Organization Mid-Life, the point where the culture's direction can be changed and managed. The company's culture currently inhibits innovation, and preserves past glories, using the latter as 
a source of self-esteem and defense. The restrictions on innovation, due to cultural barriers, can blind the company leadership to the inherent need for culture management. (Figure 5)..

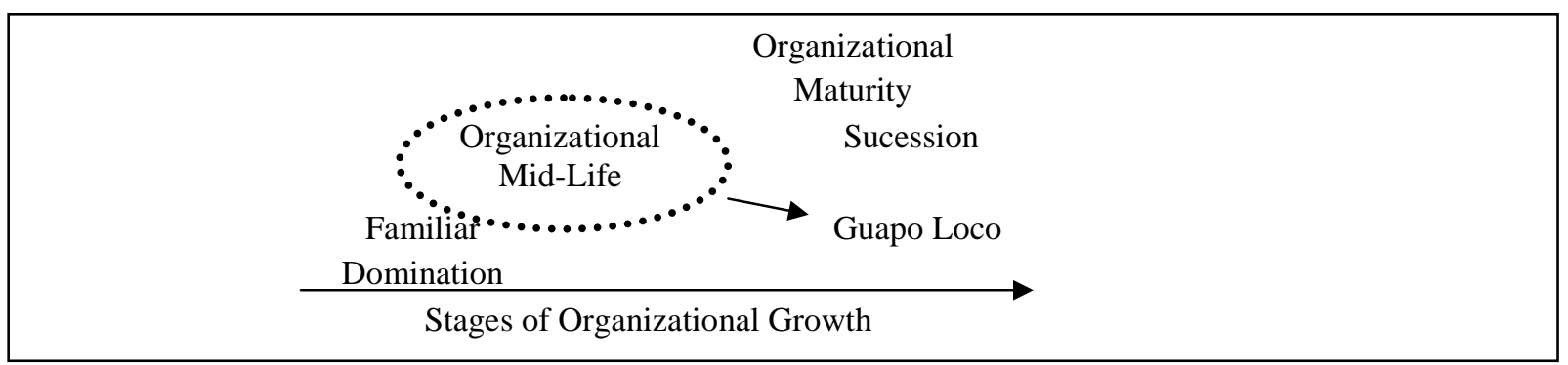

Figure 5: Stages of organizational growth

Source: Elaborate by the authors.

f) In relation to leadership, as the organizational culture has not changed from a person/power culture to a task/role culture (according to Handy's model) as it should have to follow the evolution of new strategies, businesses and the environment, the organization will face its crisis with the same methods established during the birth stage. As CEO Carlos Davies has no successors to take his place as a charismatic leader, he will not be able to manage the succession without the organizational culture's necessary evolution.

The vision that President Carlos Davies imparts to his organization abides by the principles described by Lipton (2003) and reinforces the tough-guy/Macho culture (according to Deal and Kennedy 's Model): its Raison d'être being the protection of his family at all costs; as it's informal strategy for achieving its "higher purpose", as for the Values, they are those he internalizes in the organization he creates: loyalty, but also a whole set of chauvinist values, derived from his family culture.

This situation confirms the organizational theory which states that leaders' values are standards and models regarding what is important for a society or organization. The origins of culture lie in the action of leaders and is strengthened by the leader. Many leaders make their followers believe that they need them and take their opinions into account, whereas in fact they only want to seduce them into a total acceptance of their objectives (Enriquez,1989;Tomei \& Hilal, 2006).

In organizations such as Guapo Loco, employees are sometimes subject to constant professional stress as well as to leaders that embody the personalization/ personification of power (where the hero of the myth is always present) in order to guarantee their professional recognition. President Carlos Davies thus personifies the constant exercise of power and seduction in his pursuit of immediate and absolute submission. 
We can briefly define the personalization of power as a phenomenon that is external to authority itself that allows power to be personified in the person who has it. When the personalization of power is associated with personification, we can observe the star syndrome.

The values of leaders represent not only standards but also models regarding what is important to a society or to an organization. As stated above, the origins of culture lie in the action of leaders and is strengthened by them. When an organizational culture is dysfunctional, leadership is the key instrument for learning and for the introduction of innovations. (Schein, 1985b)

In organizational environments with a culture that is extremely centered on the leader, as in the case of the Guapo Loco organization, his values must be the standard and model of this culture. Tomei \& Hilal (2006) points out that the leader sometimes submits the organization to a constant professional stress, reinforcing the leader's personification. In the case under study, this function is executed by the rituals and principles of the family culture, internalized by the founder in the organization. But the organizational culture must evolve as new strategies become necessary due to the changing competitive environment, and to accompany the evolution of the company dimension.

\section{CONCLUSIONS}

Based on the cultural diagnosis of the Guapo Loco organization, we sought to understand the impact of culture on the various phases of a family organization's life cycle and performance.

The case study enabled us to identify the existence of a paternalistic culture in the organization at issue, with a strong leadership that personalized power and hampered the organization's professionalization process.

To face the competitive and highly unstable environment found in the restaurant and bar industry in Rio de Janeiro, Guapo Loco must abandon the current culture with its paternalist approach and excessive focus on the figure of the President, where decisions are made as they were ten years ago, when the firm was still a one branch business.

As seen in the case at issue, it is possible for the succession to become trapped by the culture in which it was born, and is not able to foster the changes necessary for the organization's evolution. We saw that as it reaches maturity, the company, family and ownership dimensions all require a similar adaptation as, at this stage, the organization will sooner or later have to reinvent itself or disappear. At this stage the organization's culture can 
become dysfunctional and prevent the adaptation necessary for the succession to take place, thus jeopardizing the organization's survival.

The main objective of this work, which was to analyze the impact of culture on organizational performance, through the analysis of the Guapo Loco organization, was achieved when we showed that it would not be possible to implement the new strategies imposed by the competitive environment, without changes in organizational culture.

In the process of strategic redefinition, the alignment of culture to new objectives would be very important. Its implementation would occur only through the implementation of different management policies such as:

a) Reviewing the CEO's role and personalization of power (where the hero of the myth is always present). The group and the individual members find themselves in a fragile position, mainly when the leader is an "all powerful one" and, the followers already have the "germ of seduction" increasing the probability of being used as instruments in a pathological game. In this way, the leader will manipulate individuals, groups and cultures that are in a fragile position in terms of identity, beliefs and values. Only if this leader is excluded from this pathological place, and loses his idealized position, will the group and the culture consciously understand that it is part of the leader's style to try to place people in a position where they can be easily manipulated. But, this will only happen when results are bad and organizational leadership and culture is affecting organizational performance.

b) The detailed planning of the administrative and ownership succession process. From the cultural point of view, so that this transition can be done in a positive way for the group, it is necessary not to break the rules of the game, but to take advantage of the moment to make the required strategic changes.

c) Therefore, a very careful and detailed business plan should be prepared with a longterm view, including management and the tasks allotted to the family in the business. The good management of transition moments is vital for the survival of a family organization.

d) The hiring of people, from outside the company or the family, creating administrative and/or family committees. This provides the managerial process with an independent viewpoint and helps to mediate possible disagreements between relatives, thus avoiding impacts in the development of the business.

e) The clear explanation of the objectives, mission, and results of the family and the organization, so that the purpose and the commitment of all can be obtained. 


\section{REFERENCES}

ADIZES, L. Organizational passages: diagnosing and treating life cycle problems in organizations. Organizational Dynamics, v.8, n.1, 1979.

ANDREWS, William A.;DOWLING, Michael J. Explaning performance changes in newly privatized firms. Journal of Management Studies, Sep.1998.

ARRIGHI, Giovanni. O Longo século XX: dinheiro, poder e as origens de nosso tempo. Rio de Janeiro: Contraponto, 1996.

BARROS, B.T. de; PRATES, M.A.S. O Estilo brasileiro de administrar. São Paulo: Atlas, 1996.

CANCLINI, N.G. A Globalização imaginada. São Paulo: Editora Iluminuras, 2003.

CRUZ NETO, Otávio. O Trabalho de campo como descoberta e criação. In: SEIFFERT, Peter Quadros. Modelo de gestão humana para empresas intensivas em capital intelectual: um ensaio na Embraer S.A. 2002. Tese. Universidade Federal de Santa Catarina (UFSC), Florianópolis, 2002.

DAFT, R. Organizações, teorias e projetos. São Paulo: Pioneira Thomson Learning, 2008.

DAVIS, J. et al. Generation to generation: life cycle of family business. HBS Press Book, 1997.

DEAL, T.; KENNEDY, A. Corporate culture. Massachusetts: Addison-Wesley, 1982.

DENISON, Daniel R.; MISHRA, Aneil K. Toward a theory of organizational culture and effectiveness. Organization Science, v. 6, n. 2, mar./apr. p. 204-223, 1995.

DESSLER, G. Winning commitment. New York: McGraw Hill, 1993.

DONNELLY, R. The Interrelationship of planning with corporate culture on the creation of shared values. Managerial Planning, v. 32, may./jun. 1984.

ENRIQUEZ, Eugene. $L$ 'individu pris au piège de l'entreprise stratégique. Revue Conexions, Paris, v. 54, 1989.

FREITAS, M. E. Cultura organizacional: formação, tipologias e impacto. São Paulo: Ed. Makron Books, 1991.

GOFFEE, Rob; JONES, Gareth. What holds the modern company together? Harvard Business Review, nov./dec., p. 133-148, 1996.

GREINER, L. E. Evolution and revolution as organizations grow. Harvard Business Review, v. 50, n. 3, 1972.

HAMEL, G.; PRAHALAD, C. K. Do You really have a global strategy? In: OHMAE, K. The Evolving global economy. Harvard Business Review Book. Jul/ago. 1985. 
HANDY, C. Deuses da administração: como enfrentar as constantes mudanças da cultura empresarial. São Paulo: Saraiva, 1979.

HARVEY, David. Condição pós-moderna. São Paulo: Edições Loyola, 1992.

HOFSTEDE, G. Culturas e organizações: compreender a nossa programação mental. Lisboa: Edições Silabo, 1991.

HSM Management - Empresas Familiares - O Desafio da Continuidade. Nov-Dez. 2003.

JENSEN, M. Agency costs of free cash flow, corporate finance, and takeovers. American Economic Review, 76, p. 323-329, 1986.

KOTABE, M; HELSEN, K. Administração de marketing global. São Paulo: Atlas, 2000.

KOTLER, P. Marketing para o século XXI: como criar, conquistar e dominar mercados. São Paulo: Futura, 1999.

LANSBERG, I. The Succession conspiracy. Family Business Review, v. 1, n. 2, p. 119 143, Summer 1988.

LIPTON, M. Guiding growth: how vision keeps companies on course. Boston, Massachusetts: Harvard Business School Press, 2003.

MARCOULIDES, George E.; HECK, Ronald H. Organizational culture and performance: proposing and testing a model. Organizational Science, v. 4, n. 2, maio 1993.

PETTIGREW, A. M. On Studying organizational cultures. Administrative Science Quarterly, v. 24, n. 4, p. 570-81, 1979.

QUINN, James Brian. Strategic change: logical incrementalism. Management Review, 1998.

QUINN, R.E.; CAMERON, K.S. Diagnosing and changing organizational culture: based on the competing values framework. San Francisco: Jossey-Bass, 2006.

QUINN, R. E.; ROHRBAUGH, J. A Spatial model of effectiveness criteria: towards a competing values approach to organizational analysis. Management Science, v. 29, n. 3, p. 363-377, 1983.

SAFFOLD, Guy S. Culture traits, strength, and organizational performance: moving beyond "strong" culture. The Academy of Management Review, v. 13. n. 4, p. 546-558, oct. 1988.

SCHEIN, E. H. The Role of the founder in creating organizational culture. Organizational Dynamics, p. 13-28, summer 1983.

What You need to know about organizational culture. Training \& Development Journal, v. 40, Issue 1, p. 30, jan. 1986.

Legitimating clinical research in the study of organizational culture. Journal of 
Counseling \& Development, v. 71, Issue 6, p. 703, jul./aug. 1993.

Coming to a new awareness of organizational culture. Sloan Management

Review, v. 25, n. 2, p. 3-16, 1984.

How culture forms, develops, and changes. In: KILMANN. et al. Gaining

control of the corporate culture. São Francisco: Jossey-Bass, 1985a.

Organizational culture and leadership. São Francisco: Jossey-Bass, 1985 b.

Organizational culture. The American Phychologist, v. 45, n. 2, p. 109-119,

1990.

SCHWARTZ,S. H. A Theory of cultural values and some implications for work. Applied Psychology: an International Review, v. 48, n. 1, p. 23-47, 1999.

SEIFFERT, Peter Quadros. Modelo de gestão humana para empresas intensivas em capital intelectual: um ensaio na Embraer S.A. 2002. Tese. Universidade Federal de Santa Catarina (UFSC), Florianópolis, 2002.

SETHIA, N.; VON GLINOW, M. A. Arriving at four cultures by managing the reward system. In: KILMANN et al. Gaining Control of the Corporate Culture. San Francisco: Jossey Bass, 1985.

TOMEI, P. A. Cultura organizacional e mudança organizacional. Rio de Janeiro: Ed. PUC-Rio, 2008.

TOMEI, P. A.; RUSSO G.; ANTONACCIO, C. Cultura empreendedora. Rio de Janeiro: Ed. Office Book, 2008

TOMEI, P.; ADELSON, A. Sedução dos modismos. Rio de Janeiro: Makron Books, 1997.

TOMEI, P. A.; HILAL, A. Seductive leadership and culture of the ephemeral: case sutdy the devil wears Prada . In: GLOBAL BUSINESS AND TECHNOLOGY ASSOCIATION 2006 INTERNATIONAL CONFERENCE, 2006, Russia. Anais... Russia: ANSIA GBATA READINGS BOOK.

TROMPENAARS, F. Nas Ondas da cultura: como entender a diversidade cultural nos negócios. São Paulo: Educator, 1994.

VAKALOULIS, M. Le Capitalisme post-moderne: elements pour une critique sociologique. Paris: Presses Universitaires de France, 2001.

VIDIGAL, A. C. Viva a empresa familiar! Rio de Janeiro: Rocco, 1996.

ZAGO, C. C. Modelo de arquitetura da cultura organizacional. 2000. Dissertação.

Universidade Federal de Santa Catarina (UFSC), Florianópolis, 2000. 